\title{
Radiological impact of oil and Gas Activities in selected oil fields in Production Land Area of Delta State, Nigeria
}

\section{${ }^{* 1}$ EZEKIEL O. AGBALAGBA; ${ }^{2}$ GREGORY O. AVWIRI; ${ }^{3}$ YEHUWDAH E. CHAD- UMOREN}

\author{
${ }^{1}$ Department of Physics, Federal University of Petroleum Resources, Effurun, Delta State, Nigeria. \\ ${ }^{2,3}$ Department of Physics, University of Port Harcourt, Port Harcourt, Rivers State, Nigeria
}

ezeke64@yahoo.com,goavwiri@yahoo.com, echadumoren@yahoo.com

Keywords: Radiological impact, Oil and Gas facilities, oil field, ionizing radiation levels.

\begin{abstract}
A study of the radiological impact of oil and gas exploration activities in the production land area of Delta State has been carried out in-situ using two synchronized and calibrated radiation meters (Digilert 50 and 100) and a geographical positioning system (GPS). Ten oil field facilities were studied. At each facility, nine sampling locations and their host communities were evaluated making a total of 100 study points. Measured exposure rate in the oil field facilities ranged from $0.011 \pm 0.003 \mathrm{mRh}^{-1}$ in Evwreni camp site to $0.031 \pm 0.01 \mathrm{mRh}^{-1}$ at the Otorogu gas plant. Mean field exposure rates/equivalent dose rates ranged from $0.016 \pm 0.006 \mathrm{mRh}^{-1}\left(0.839 \pm 0.34 \mathrm{mSvy}^{-1}\right)$ to $0.0213 \pm 0.008 \mathrm{mRh}^{-1}\left(1.134 \pm 0.44 \mathrm{mSvy}^{-}\right.$ $\left.{ }^{1}\right)$. In the host communities the values ranged from $0.0115 \pm 0.003 \mathrm{mRh}^{-1}\left(0.612 \pm 0.16 \mathrm{mSv}^{-1}\right)$ in Evwreni community to $0.021 \pm 0.007 \mathrm{mRh}^{-1}\left(1.117 \pm 0.37 \mathrm{mSvy}^{-1}\right)$ in Otujeremi town, while for the control study area the value obtained was $0.009 \pm 0.002 \mathrm{mRh}^{-1}\left(0.479 \pm 0.11 \mathrm{mSvy}^{-1}\right)$. The results show that the radiation levels for the Ughelli East, Kokori, Eriemu, Evwreni, Eriemu, Oweh, Olomoro-Oleh oil and gas fields are within the $1 \mathrm{mSvy}^{-1}$ maximum permissible limit recommended for the public and non-nuclear industrial environment, while the levels for the fields at Otorogu, Ughelli West, Afiesere and Uzere West and East and the host communities of Olomoro, Uzere and Emeragha exceeded the maximum recommended value, an indication that the oil fields and host communities environment have been impacted radiologically. However, these results obtained may not have immediate health hazard, but will pose some long-term health side effects on the staff working in the facilities and residents of the host communities. Interim proactive measures are recommended @ JASEM
\end{abstract}

DOI: http://dx.doi.org/10.4314/jasem.v17i2.11

Radiation plays an important and sometimes vital role in our everyday lives. Everyday each of us is exposed to naturally occurring quantities of radiation through the air we breathe, the soil on which we walk the water we drink, the food we eat and even within our bodies (Ademola, 2008). Furthermore, certain industrial activities such as crude oil exploration result in enhanced ionizing radiation in the environment. Ionizing radiations such as $\alpha, \beta$ and $\gamma$ radiations are often found in the petroleum matrix due to both contamination by radionuclides in the earth's crust and the materials used in the drilling process (Chad-Umoren, 2012; Laogun et al., 2006). Gamma rays are highly penetrating and are products of the radioactive materials containing radon. These substances may be ingested or inhaled thereby exposing both the hydrocarbon industry personnel and members of the host communities to increase in the risk of lung cancer, eye cataracts and mental imbalance (Laogun et al., 2006). Also, it has been reported that naturally occurring radioactive materials (NORMS) associated with oil and gas production *Corresponding author's email: ezeke64@yahoo.com contain radioactive uranium, thorium and their progenies Ra-226 and Ra-228 (Abison, 2001; Avwiri et al., 2007a; Chad-Umoren, 2012).

Radiation monitoring is of primary importance for environmental protection purposes (El-Bahi, 2004). A strong correlation has been found between oil and gas activities and elevated environmental ionizing radiation (Avwiri et al., 2007a; Avwiri et al., 2007b; Chad-Umoren, 2012; Chad-Umoren and BriggsKamara, 2010; Ononugbo et al., 2011) which are attributed to the industries' input raw materials and effluent discharge such as gas flaring and other output products.

Elena and Gracea (2004) conducted environmental monitoring of radioactivity in the environs of six oil fields in Bacau and Braila districts and reported that there was no immediate radiological challenge; however, the high radium-226 content of oil field formation waters could lead to environmental pollution. Laogun et al. (2006) studied the variation 
in well-head gamma radiation levels at an oil field in Ologbo, Edo state in the Niger delta region of Nigeria and reported that though the values obtained were somewhat higher than the normal background level, they were in agreement with the International Atomic Energy Agency's standard on background ionizing radiation level for such environment.

Avwiri et al. (2007) studied the terrestrial radiation at oil and gas facilities in Ughelli region of Nigeria and reported a range of $12.00 \pm 0.1 \mu \mathrm{Rh}^{-1}$ $(5.33 \pm 0.35 \mu \mathrm{Sv} / \mathrm{wk})$ to $22.00 \pm 2.1 \mu \mathrm{Rh}^{-1}(9.79 \pm 0.16)$ in the oil fields and $09.00 \pm 1.0$ to $11.00 \pm 0.5 \mu \mathrm{Rh}^{-1}$ in the host communities. They concluded that though the radiation values were within international standards and in agreement with other reported values for similar areas of the country, the background ionizing radiation (BIR) levels exceeded the normal background level.

It is known that the more radiation dose from oil and gas installation a person receives, the greater the chance of developing cancer, leukaemia, eye cataracts, haematological depression and incidence of chromosome aberrations (EPA, 2009). This may not appear until many years after the radiation dose is received (typically, 10-40years).

This present study aims at assessing the radiological impact on both the environment and the population of the non-nuclear oil and gas industry in parts of Delta state, Nigeria. The study will also furnish baseline data on the background ionizing radiation (BIR) profile of the flow stations and their host communities and add to existing research information on the radiological profile of oil facilities in the region. The health implications on the personnel and residents of the host communities will also be examined.

\section{EXPERIMENTAL METHOD}

Study Area:The study area is located in Oil Mining Lease 30 (OML 30) onshore of Niger Delta (SPDC, FDP, 2004) and encompasses five local government areas of Delta State (Isoko North and South, Ughelli North and South and Ethiope East L.G). It comprises ten oil fields and lies within latitudes $5^{0} 18^{\prime \prime} \mathrm{N}$ and $5^{\circ} 86^{\prime \prime} \mathrm{N}$ and longitudes $5^{\circ} 33$ "E and $6^{\circ} 40$ E", southwest of the Niger Delta region of Nigeria (UNDP, 2006) (Fig.1). The main geological elements of the area, at varying depths in thousands of meters, are the Benin formation, which is the youngest, underlain by the Agbada formation and followed by the oldest, the Akata formation (Doust and Omatsola, 1990). The three formations are differentiated by their ages and by their degrees of compaction. Their ages become progressively younger in down-dip direction (Taiwo and Akalia, 2009).

The Benin formation is composed mainly of sand, gravel and shale. The minor components of the formation include limonite coating, lignite streaks, hemalite and feldspar. Insignificant quantity of oil has been found in the formation. It is the major source of groundwater in the Niger delta. The lithologies of the Agbada formation are composed of alternating layers of sandstones, silts and shales, while the sandstone reservoirs account for the oil and gas wealth of the region. The Akata formation is composed of dark gray shales and silts with some streaks of sand of turbidite flow origin.

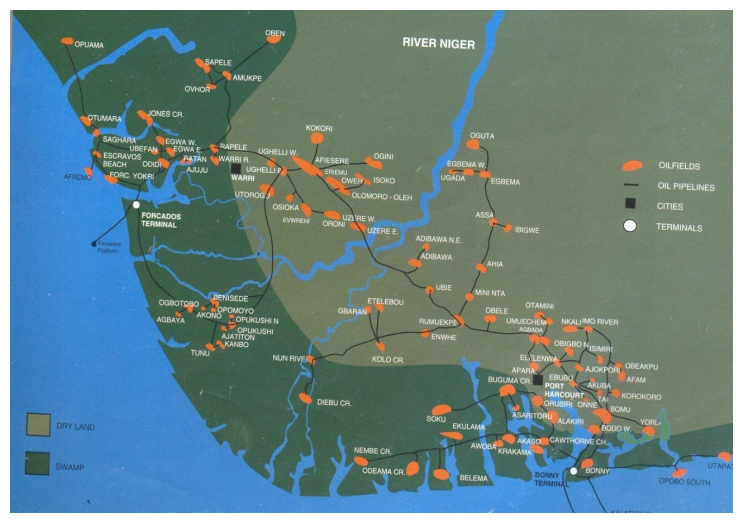

EZEKIEL O. AGBALAGBA; GREGORY O. AVWIRI; YEHUWDAH E. CHADUMOREN 
ERROR: stackunderflow

OFFENDING COMMAND:

STACK : 